\title{
Chemical and technological studies on some formula from seeds and beans
}

Adel Abd-Elmotty; Nehad ,R. EL-Tahan and Aya , M.E.

Nutrition and Food Science Dep., Home Economics Faculty, Menoufiya

University, Egypt.

\section{ABSTRSCT}

Consumption of meat had faced some problems such as microbial growth and shortage of the shelf life because of the cross contamination during processing and handling. In this study,wheat, lentil, chickpea, carrot, soybean and mushrooms were used to prepare burger formula from planted sources and these formula comparing with commercial burger which produced from meat. Chemical composition, $\mathrm{PH}$ value, color, total volatile nitrogen, thiobarbituric acid value, microbiological evaluation and sensory evaluation weredetermined in tested samples. From the results, it could be found that the planted burger had high quantity of ash, carbohydrates and low content of fat.The color changes during storage was rapid than the plant burger sample. The total volatile nitrogen content was more pronounced in commercial burger than burger samples. Commercial burger had higher microbial count than the burger samples at the beginning of storage and spoiled after only 15 days at $4^{\circ} \mathrm{C}$, while the plant burger samples was spoiled after 30 days. Organoleptic evaluation showed that the burger samples had the best order of over acceptability followed by the Beefburger.

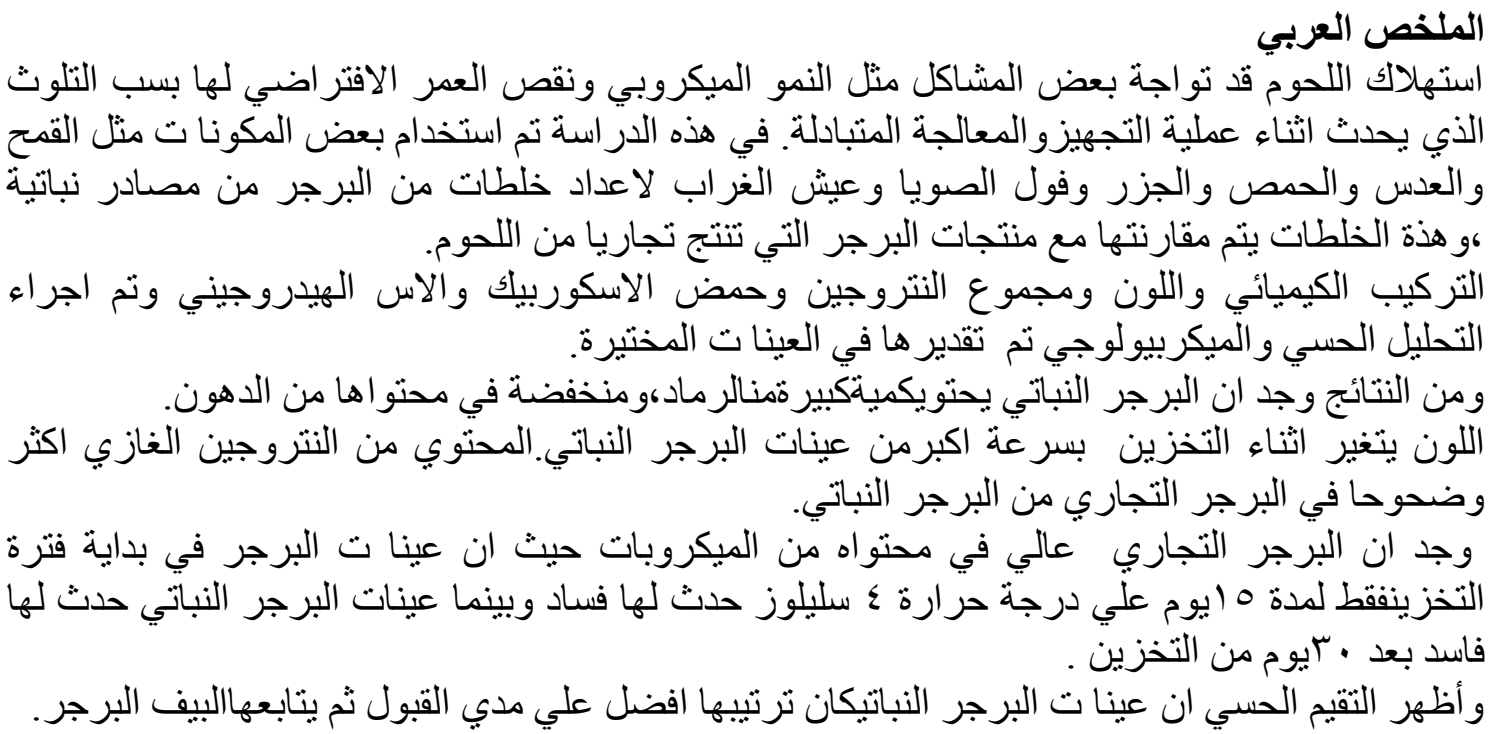




\section{INTRODUCTION}

Meat and meat products are one of the most consumed foods in Western diets.

Meat has a high nutritional value due to its high content of macronutrients, such as highly nutritious proteins, and micronutrients, such as iron, which makes meat a good product for everyone.

However, some essential micronutrients for human health are not present naturally in meat or meat products. One example is folic acid (FA), a watersoluble vitamin that is almost absent from meat products and that plays an important role in human metabolism. Folic acid is important mainly for the biosynthesis of purines and pyrimidines, methionine and serine; it is also implicated in the metabolism of histidine andhomocysteine(Stranger, 2002).

Wheat is one of the oldest food crops grown by man, which has achieved a central role as a staple food for all the nations and cultures. This is because of its flour having unique property of forming a cohesive dough and thus to be made into leavened bread and many range of noodles, soups, pasta and other foods. Wheat contributes most of the nutrients to humans compared to other cereals. About $44 \%$ of protein and $40 \%$ of fat are provided by wheat compared to other cereal grain sources. This highlights the importance of wheat as food grain. Wheat grain develops proteins, starch, lipids and sugars that accumulate in the endosperm for the embryonic wheat plant(Uthayakumaran and Wrigley, 2010).

The nutritional potential of these seeds is based on their high level of protein and, depending on species, a high proportion of either starch or oil. They are generally good sources of slow-release carbohydrates and are rich inproteins (18-25\%); soybean is unique in containing about $35-43 \%$ proteins. Along with macronutrients, leguminous seeds contain appreciable amounts of vitamins, minerals, dietary fiber and a number of health-promoting bioactive substances including phenolics(Guillon and Champ,2002).

Vegetables are an important part of human diet. it provide, not only the major dietary fiber component of our food, but also a range of micronutrients, including minerals, vitamins and antioxidant compounds, such as carotenoids and polyphenols. The nutritional value of fruit and vegetables is often associated with their antioxidant capacities (Vinson et al. 1998 and Chu et al. 2002).

Legumes, an excellent source of protein, play an important role in human nutrition and are the staple food in many regions of the world. Biotechnological processes such as germination and fermentation are simple and economic methods to improve the nutritive value of legumes by causing desirable changes in nutrient availability, texture and organoleptic characteristics (Granito et al .2005).

Grain legumes are important sources of food proteins and dietary fibers, as well as, basic constituents of the Mediterranean diet. Mediterranean diet has proven to be beneficial in human health(Pérez-López et al.2009). 


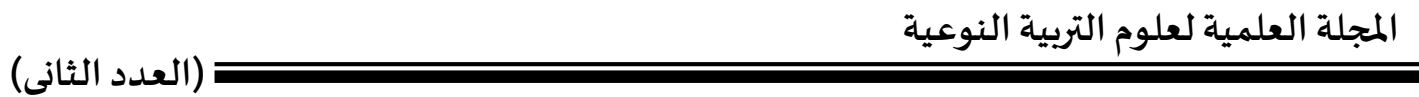

Lentils are an important dietary source of complex carbohydrates, fiber,minerals, vitamins, antioxidant compounds, and proteins, although the quality of the protein is low(Porres et al .2003)with a chemical score of 88 and a protein digestibilitycorrected amino acid score of $71.2 \pm 0.42$ (Porres et al .2001).

Mushrooms belong to macro-fungi which are grown worldwide. There are more than 14,000 species of mushrooms, and at least 2000 of them have various degrees of edibility, of which about 200 edible mushrooms are wild species (Chang, 2008 and Kala. 2012).

Edible mushrooms with a special umami taste belong to the food group with exceptionally rich nutritive value in vegetable proteins, vitamins, minerals and chitin, while low in calories and fat (Ranogajecet al.2010). Specific organoleptic characteristics of mushrooms and urge for a well-balanced diet led to a worldwide increase in consumption of edible mushrooms (Ranogajec et al. 2010and Wasser, 2011).

Mushrooms can also be used for therapeutic purposes, since they can produce a large variety of secondary metabolites, such as organic acids, alkaloids, terpenoids, steroids and phenolic compounds (Jayakumarset al. 2011).

Soybeans [Glycine $\max$ L. (Merr.)] are one of the major agricultural commodities in the world. This species is a widely used crop because of its valuable beneficial health effects on several chronic diseases, including the prevention of cancer, cardiovascular disease, and multiple conditions ameliorated by antioxidants (Zhang $\boldsymbol{e t ~ a l . ~ 2 0 1 1 ) . ~}$

All the ingredientsthe definition of dietary fiber (DF) proposed by American Association of Cereal Chemists (AACC) defines DF being made up of edible part of plants or analogous carbohydrates that are resistant to digestion and absorption in the human small intestine as well as having beneficial physiological effects such as laxation, blood glucose attenuation and/or blood cholesterol attenuation (AACC, 2000). More specifically, dietary fiber means carbohydrate polymers with ten or more monomeric units, which are not hydrolyzed by the endogenous enzymes in humans These non-digestible carbohydrate (NDC) polymers should occur naturally in the food as consumed and have been obtained from food raw material by physical, enzymatic or chemical means and which have been shown to have a physiological effect of benefit to health as demonstrated by generally accepted scientific evidence to competent authorities(Codex, 2001).

\section{MATERIALSAND METHODS \\ Materials}

All ingredients ofmeat, wheat, lentil, chickpea, carrot, soybean and mushrooms were purchasedfromthe local markets .atChemicals which used in this study were obtained from GomhoriaCo. Dokki,Giza. 


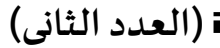

\section{Methods}

\section{Preparation of beef burger}

Beef burgers as control samples were prepared using the following formula The using ingredients are summarized in Table (A).

Beef meat minced and all ingredients were mixed in Hobart (modelC.100) speed no.2(a laboratory cutter) for $10 \mathrm{~min}$. The mixture was then shaped in a circular burgers of $10 \mathrm{~cm}$ diameter, $0.5 \mathrm{~cm}$ thickness and about $60 \mathrm{gm}$ weight. Each piece was surrounded with two pieces of butter paper before packaging in polyethylene bags (about $0.5 \mathrm{~kg}$ capacity) (Bennion andBamford, 1973).

Table(A): Recipes used in the preparation of experimental burger samples containing different levels of components.

\begin{tabular}{|l|l|l|l|l|}
\hline Ingredients(\%) & Control & Sample(1) & Sample(2) & Sample(3) \\
\hline Leanmeat (beef) & 67.00 & - & - & - \\
\hline Toasted bread meal & 17.00 & - & - & - \\
\hline Whole egg & 7.00 & 7.00 & 7.00 & 7.00 \\
\hline Salt & 1.70 & 1.70 & 1.70 & 1.70 \\
\hline Black pepper & 0.30 & 0.30 & 0.30 & 0.30 \\
\hline Onion & 7.00 & 7.00 & 7.00 & 7.00 \\
\hline Wheat & - & 47.30 & 47.3 & 47.30 \\
\hline Cicerarietinum & - & - & 15.00 & - \\
\hline Cicer & - & 15.00 & - & - \\
\hline Vignamungo & - & 11.70 & - & 11.70 \\
\hline Lens culinaris & - & - & 11.7 & \\
\hline Mushrooms & - & 10.00 & - & 10.00 \\
\hline Carrot & - & - & 10.00 & - \\
\hline Soybean & - & - & - & 15.00 \\
\hline
\end{tabular}

\section{Cooking of the burgers}

All the burgers sampleswere cooked during 2 min on each side using a grill previously heated to $150{ }^{\circ} \mathrm{C}$. The temperature inside the burger samples reached approximately $60{ }^{\circ} \mathrm{C}$, as measured by a portable digital thermometer (Testo model 735; Testo, S.A., Barcelona, Spain). This treatment was sufficient to obtain a good final degree of doneness. All samples were storage at cold temperature $4^{\circ} \mathrm{C}$ for 45 days.

\section{Analytical methods}

Moisture,protein (T.N $\times 6.25$, micro-Kjeldahl method using semiautomatic apparatus,Velpcompany ,Italy), Fat (Soxheltsemiautomatic apparatus Velp company, Italy, petroleum ether solvent ), ash and fiber contents were determined using the methods described in the (A.O.A.C,1995).Carbohydrates calculated by Differencesas follows:

Carbohydrates $(\%)=100-(\%$ moisture $+\%$ protein $+\%$ fat+\% Ash $+\%$ Fiber $)$. 
The $\mathrm{PH}$ value was measured by a $\mathrm{PH}$ meter according the method of Aitken et al. (1962).

Color of the samples was measured using a spectrocolorimeterTristimulus color Machine, with CIE Lab Color Scale. This color assessment system is based on Hunter L,a and b coordinates according to Hunter (1958).

Total volatile nitrogen (TVN) was estimated by the method of

\section{Winton and Winton (1958) .}

\section{Microbiological examination:}

Aerobic plate count was determined on plate count agar medium after inoculation with a suitable dilution. The poured plates were incubated at $32^{\circ} \mathrm{C}$ for $48 \mathrm{~h}$. (Harrigan and Margaret, 1966).

\section{Sensory evaluation and statistical analysis}

Sensory evolution of the control beef burger and different burger samples with different plants( wheat, lentil, chickpea, carrot, soybean and mushrooms) was carried out. Firstly, fifteen panel testers were employed to evaluate organoleptic flavor to chose the best burger formula. Secondly, the panelist were employed to evaluate organoleptically the color, odor, taste, texture and over all acceptability of all samples under investigation. Sensory of properties evaluated in Nutrition and Food Science Department,Minufia University according to Bennion and Bamford,( 1973).

Ranking method was used to find out the best product which had the lowest sum of ranks. The critical values of differences among the sum of ranks were used for testing the significant differences between the products where the significant is attained when the rank sum differences are greater than or equal to the critical differences ( Basker,1988).

\section{Results and discussion}

1- Gross chemical composition

Table (1) shows proximate gross chemical composition of cooked commercial and planted burgers on wet weight base.From these data, it could be observed that commercial beefburgur contained $32.01 \%$ moisture, $28.76 \%$ protein, $36.51 \%$ fat, $1.79 \%$ ash and $0.93 \%$ carbohydrates. Sample A contained high level of carbohydrates and Sample $\mathrm{C}$ had higher content of protein, fat and ash when compared with the other planted burger samples.From the Table(1), it could be noticed that the commercial hamburger had higher content of moisture than the other samples, this may be due to the high ercontent of moisture in raw material. Sample $C$ had higher content inprotein more than the other plant burger sample, this due to the high content of soy bean. All plant burger samples were lower in fat than the commercial hamburger and it could be healthy for more diseases as diabetics, hypercholesterolemic and heart disease(Guillon and Champ, 2002). 


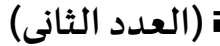

Table (1): Chemical composition of cooked plant and commercial burger samples on wet weight base.

\begin{tabular}{|l|c|l|l|l|}
\hline Components \% & beefburger & Sample A & Sample B & Sample C \\
\hline $\begin{array}{l}\text { Moisture } \\
\text { content }\end{array}$ & 32.01 & 12.2 & 13.93 & 12.2 \\
\hline Protein content & 28.76 & 14.43 & 13.5 & 22.68 \\
\hline Fat content & 36.51 & 2.13 & 2.1 & 5.80 \\
\hline Ash content & 1.79 & 2.54 & 2.8 & 3.21 \\
\hline $\begin{array}{l}\text { Total } \\
\text { carbohydrates }\end{array}$ & 0.93 & 68.7 & 67.67 & 56.11 \\
\hline
\end{tabular}

2-The PHvalue of planted burger and commercial burger samples during cold storage at $4^{\circ} \mathrm{C}$.

The $\mathrm{PH}$ values of planted burger and commercial burger samples were measured during cold storage. obtained results are shown in Table (2) it was noticed that, slight differences were found between burger samples in the beginning of storage, but the values of $\mathrm{PH}$ values were decreased at the end of storage period. This may be ascribed to The effectof hydrolytic contaminant bacteria (Kala,2012). From the Table(2), it could be noticed that commercial hamburger sample recorded a little lower values of $\mathrm{PH}$ than the other samples during storage. The highest ph value at the end of storage period was recorded by plant burger (sample C) which was 5.5, this may be referred to higher phenolic compounds, vitamin $\mathrm{A}$ and $\mathrm{C}$ which found in burger sample which play a role as an antimicrobial effect (Chu et al., 2002).

Table (2): The $\mathrm{PH}$ value of plant burger and commercial burger samples during cold storage at $4^{\circ} \mathrm{C}$.

\begin{tabular}{|l|c|c|c|c|}
\hline \multirow{2}{*}{ Samples } & \multicolumn{4}{|c|}{ Storage period } \\
\cline { 2 - 5 } & 0 & 15 & 30 & 45 \\
\hline Hamburger & 5.3 & 5.1 & 4.8 & 4.6 \\
\hline Sample A & 5.9. & 5.9 & 5.3 & 5 \\
\hline Sample B & 6.1 & 6 & 5.7 & 5.3 \\
\hline SampleC & 6.1 & 5.9 & 5.9 & 5.5 \\
\hline
\end{tabular}

3 -Changes in hunter color values of the plant burger and commercial burger samples during cold storage.

Hunter color values of the different plant burger samples and commercial hamburger were measured during cold storage at $4 \mathrm{C}$ up to 45 days as $\mathrm{L}$, $\mathrm{a}$ and $\mathrm{b}$ values. Results are shown in Table (3). From the obtained results, it could be observed that, the Hunter "L" value of commercial at zero time of storage (35.82) was higher than the other samples followed by the planted burger (sample C) ( 35.69). The differences between these samples were not pronounced. Plant burger sample A had the lowest "L" value ( 34.08 ). It could be also noticed that 
"L" values increased during storage of all samples while decreased for the hamburger sample. From the same Table(3), It could be found that the commercial hamburger was the most reddish as hunter "a" (7.5) . However, concerning plant burger samples, it could be stated that, sample contained mushrooms, chickpea and lentil increased the " $+\mathrm{a} "$ value .This may be due to the effect of protein and phenolic acids content of on the samples color. The red color degradation of commercial hamburgerwas more than that of the plant samples. From the same table, it could be noticed that, the hunter yellowness values $(+b)$ increased during cold storage plant burger samples while, in case of commercial hamburger was decreased .

Table (3): Changes in hunter color values of plant burger and commercial burger samples during cold storage at $4^{\circ} \mathrm{C}$.

\begin{tabular}{|l|c|l|l|l|l|}
\hline Samples & Hunter color & \multicolumn{4}{|c|}{ Storage period } \\
\cline { 2 - 6 } & & 0 & 15 & 30 & 45 \\
\hline \multirow{4}{*}{ Beefburger } & $\mathrm{L}$ & 35.82 & 35.71 & 34.72 & 33.34 \\
\cline { 2 - 6 } & $\mathrm{a}$ & +7.50 & +7.07 & +5.43 & +4.18 \\
\cline { 2 - 6 } & $\mathrm{b}+$ & +13.52 & +13.32 & +12.11 & +11.64 \\
\hline Sample A & $\mathrm{L}$ & 34.08 & 34.22 & 35.13 & 37.30 \\
\cline { 2 - 6 } & $\mathrm{a}$ & +5.44 & +5.30 & +5.29 & +5.09 \\
\cline { 2 - 6 } & $\mathrm{b}+$ & +15.6 & +15.55 & +15.41 & +16.02 \\
\hline Sample B & $\mathrm{L}$ & 34.55 & 35.36 & 35.62 & 39.05 \\
\cline { 2 - 6 } & $\mathrm{a}$ & +5.83 & +5.84 & +5.60 & +5.43 \\
\cline { 2 - 6 } & $\mathrm{b}+$ & +14.66 & +14.50 & +14.78 & +15.44 \\
\hline SampleC & $\mathrm{L}$ & 35.69 & 35.80 & 35.76 & 40.54 \\
\cline { 2 - 6 } & $\mathrm{a}$ & +6.65 & +6.14 & +5.80 & +5.50 \\
\cline { 2 - 6 } & $\mathrm{b}+$ & +14.90 & +14.80 & +14.23 & +15.88 \\
\hline
\end{tabular}

4-Total volatile nitrogen values of planted burger and commercial burger samples during cold storage at $4^{\circ} \mathrm{C}$.

Table (4) indicates total volatile nitrogen (T.V.N.) in cooked planted burger and commercial burger samples during storageat $4{ }^{\circ} \mathrm{C}$ up to 45 days. From the obtained data, it could be observed that, there was gradual increase in TVN during cold storage of commercial Beefburger. This due to protein hydrolytic activity of contaminatingorganisms. The increasing of this parameters may be led to insanitary procedure during processing of commercial burger(Stranger, 2002). The value of TVN was higher in case of sample A followed sample B and the last one sample $\mathrm{C}$. This may be due to antimicrobial effect of phenolic acids and the antioxidants content of plant burger samples(Ranogajecet al.2010).

Table (4): Total volatile nitrogen values of plant burger and commercial burger samples during cold storage at $4^{\circ} \mathrm{C}$.

\begin{tabular}{|l|c|c|c|c|}
\hline \multirow{2}{*}{ Samples } & \multicolumn{4}{|c|}{ Storage period (days) } \\
\cline { 2 - 5 } & 0 & 15 & 30 & 45 \\
\hline Beefburger & 14.5 & 14.9 & 23.6 & 40.9 \\
\hline Sample A & 14.0 & 14.5 & 21.3 & 32.5 \\
\hline Sample B & 13.7 & 14.9 & 20.8 & 30.9 \\
\hline SampleC & 12.8 & 13.5 & 17.8 & 23.9 \\
\hline
\end{tabular}


5- Microbial evaluation of planted burger and commercial burger samples during cold storage at $4^{\circ} \mathrm{Cupto} 45$ days..

From Table (5), it could be found that there is no microbial count at zero time for all samples which was due to cooking until internal temperature of $75^{\circ} \mathrm{C}$. This is due to the heat of cooking which led to kille the vegetative cells (Brock,2009).

After 15 days in the cold storage, the total count was still in the range of allowance because it was less than $1 \times 105 \mathrm{cfu} / \mathrm{g}$ (Speck, 2008). After 30 days, the total count they increased. This count led to increasePHvalue and TVN and after 45 days storage they increased and become spoilage because the range was higher than the total count limit .

Table (5): Microbial evaluation of plant burger and commercial burger samples during cold storage at $4^{\circ} \mathrm{C}$.

\begin{tabular}{|l|c|c|c|c|}
\hline \multirow{2}{*}{ Samples } & \multicolumn{4}{|c|}{ Storage period } \\
\cline { 2 - 5 } & 0 & 15 & 30 & 45 \\
\hline Beefburger & $2 \times 10^{4}$ & $5 \times 10^{5}$ & $7 \times 10^{7}$ & $5 \times 18^{8}$ \\
\hline Sample A & $3 \times 10^{2}$ & $7 \times 10^{3}$ & $1 \times 10^{5}$ & $5 \times 10^{7}$ \\
\hline Sample B & $1 \times 10^{2}$ & $6 \times 10^{3}$ & $2 \times 10^{6}$ & $4 \times 10^{6}$ \\
\hline SampleC & $1 \times 10$ & $2 \times 10^{2}$ & $2 \times 10^{3}$ & $5 \times 10^{4}$ \\
\hline
\end{tabular}

6- Sensory evaluation of planted burger and commercial burger samples during cold storage at $4^{\circ} \mathrm{C}$.

The samples under investigation were sensorially evaluated for color, odor, texture, taste and over all acceptability and the results were statically analyzed . The results are shown in tTable (6). From these data, it could be noticed that, the best color was that of the commercial hamburger followed that sample $\mathrm{C}$ with nonsignificant differences. There is no significant differences between samples in case odor, taste, texture and over all acceptability.Adding the carrot, soy bean , lentil and mushroom led to improve the sensory properties of the samples when compared to commercial hamburger(Pérez-López et al.,2009).

Table (6): Sensory evaluation of plant burger and commercial burger samples during cold storage at $4^{\circ} \mathrm{C}$.

\begin{tabular}{|l|c|c|c|c|c|}
\hline \multirow{2}{*}{ Samples } & \multicolumn{5}{|c|}{ Storage period(days) } \\
\cline { 2 - 6 } & Color & odor & Taste & Texture & $\begin{array}{c}\text { Over all } \\
\text { acceptability }\end{array}$ \\
\hline Hamburger & $9^{\mathrm{a}}$ & $9^{\mathrm{a}}$ & $9^{\mathrm{a}}$ & $9^{\mathrm{a}}$ & $9^{\mathrm{a}}$ \\
\hline Sample A & $8^{\mathrm{b}}$ & $9^{\mathrm{a}}$ & $9^{\mathrm{a}}$ & $8.7^{\mathrm{a}}$ & $8.9^{\mathrm{a}}$ \\
\hline Sample B & $8^{\mathrm{b}}$ & $9^{\mathrm{a}}$ & $9^{\mathrm{a}}$ & $8.8^{\mathrm{a}}$ & $9^{\mathrm{a}}$ \\
\hline SampleC & $8.5^{\mathrm{a}}$ & $9^{\mathrm{a}}$ & $9^{\mathrm{a}}$ & $9^{\mathrm{a}}$ & $9^{\mathrm{a}}$ \\
\hline
\end{tabular}

\section{Conclusion}

From the obtained results it could be concluded that, using mixture of wheat ,lentil, chickpea with carrot, mushroom and soybean to produce three formulas according burger methods led to obtain products had low content of fat, high in ash and carbohydrates. The color, PH value and sensory properties were nearly when compared with commercial hamburger. 


\section{References}

Aitken , A.; Casey, S.J. and Voly, C.A.(1962) Effect of drying temperature in the accelerated freeze drying of pork. J.Sci.Food Agric.,13:439-442.

A.A.C.C .(2000)Report, The definition of dietary fiber, Cereal Foods World 46 $112-129$.

A.O.A.C.(1990)Official Methods of the Assocition of official Analytical Chemists "16Ed.published by the association of official chemists Arlington, Virginia,usa.

Basker, D.(1988): Critical values of difference among sums for multiple comparison . Food Technology, (2): 79-83.

Bennion ,E.B and Bamford ,D.S.T(1973)Cake -making process .The Technology of Cake Making 5 ed Leonard hell Book prented in great Britain by Billing and Sons; Itd. Guilford and London.

Brock ,U.A. (2009) Biology of Microorganisms Prentice Hall, Inc., Englewood Cliffs, New Jersey, 07685, USA.

Cheung, P.C.K. ( 2008)NutritionalValue and Health Benefits of Mushrooms, in: P.C.K. Cheung (Ed.), Mushrooms as Functional Foods, Wiley, Hoboken, , pp. 71-110.

Chu, Y. F.; Sun, J.; Wu, X. Z, and Liu, R. H. (2002)Antioxidant and anti proliferative activities of common vegetables. Journal of Agricultural and Food Chemistry, 50(23), 6910-6916.

Codex, A. $(2 \cdots 1)$ Dietary fiber moves back into mainstreamReport of the $31 \mathrm{st}$ session of the Codex Committee on nutrition and foods for specific dietary uses, ALINORM A.E. Sloan, , Food Technol.( 55)18.

Granito, M.; Torres, A.;Frıas, J.; Guerra, M.and Vidal-Valverde, C. (2005) Influence of fermentation on the nutritional value of two varieties of Vignasinensis. European Food Research and Technology, 220:176-181.

Guillon,F.and Champ M.M.J. (2002)Carbohydrate fractions of legumes: uses in human nutrition and potential for health. Br J Nutr 88:S293-S306.

Harrigan,W.F. and Margaret, E.( 1966) Laboratory Methods in Microbiology . Academic press, London, Torento.

Hunter, R.S.(1958)Photoelectric color differences meterJ.O. Soc. Am. , 48(12)31.

Jayakumar, T.;Thomas, P. A.; Sheu, J. Rand Geraldine, P. (2011) In-vitro and in-vivo antioxidant effects of the oyster mushroom Pleurotusostreatus. Food Research International, 44: 851e861.

Kala,C. P. (2012): A review of chemical composition and nutritional value of wild-growing and cultivated mushrooms". Journal of the Science of Food and Agriculture, 93(2), 209e218.

Perez-Lopez, F.R.; Chedraui, P.; Haya, J.q.and Cuadros, J.L.(2009)

Effects of the Mediterranean diet on longevity and age-related morbid

Conditions.Maturitas; 64:67-79. 


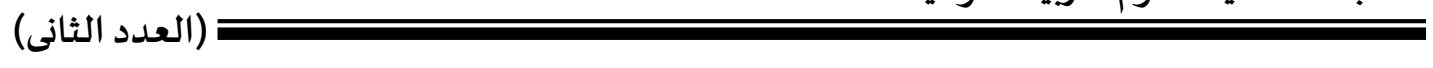

Porres J.M.; Lo'pez-Jurado M.; Aranda P .and Urbano G.(2003) Effect of heat treatment and mineral and vitamin supplementation on the nutritive use of protein and calcium from lentils in growing rats. Nutrition;19:451

Porres J.M.; Urbano G and Fernandez-Figares I, (2001)Digestive utilisation of protein and amino acids from raw and heated lentils by growing rats. J Sci Food Agric.,82:1740.

Ranogajec, A.; Beluhan, S.andSmit, Z. (2010) Analysis of nucleosides and monophosphate nucleotides from mushrooms with reversedphase HPLC. Journal of Separation Science, 33(8), 1024-1033.

Speak , M.L. (2008) Compendium of methods for the microbiological examination of foods. American Public Health Association, 1015 Eighteenth Street, Washington DC 20045.

Stranger, O. (2002)Physiology of folic acid in health and disease.Current Drug Metabolism( 3):211-223.

Uthayakumaran, S.andWrigley, C. W. (2010) Wheat: characteristics and quality requirements. In C. W. Wrigley, \& I. L. Batey (Eds.), Cereal Grains Assessing and Managing Quality (pp. 59e111). New Delhi: Woodhead Publishing Limited.

Vinson, J. A.; Hao, Y.; Su, X. H.andZubik, L. (1998) Phenol antioxidant quantity and quality in foods: Vegetables. Journal of Agricultural and Food Chemistry, 46(9), 3630-3634.

Wasser, S. P. (2011) Current findings, future trends, and unsolved problems in studies of medicinal mushrooms. Applied Microbiology and Biotechnology", 89(5), 1323e1332.

Winton, A.L. and Winton, R.B.(1958)Okoloff magnesium oxide distillation Volumetric method. The analysis of food 848, john Willy, New York.

Zhang, R. F.; Zhang, F. X.;Zhang, M. W.; Wei, Z. C.; Yang, C. Y.; Zhang, Y.; Tang, X. J.;Deng, Y. Y.and Chi, J. W. (2011)Phenolic composition and antioxidant activity in seed coats of 60 Chinese black soybean (Glycine max L. Merr.) varieties. Journal of Agricultural and Food Chemistry, 59, 5935-5944. 